\title{
Economic Feasibility and Resource Use Efficiency of Coastal Cage Fish Farming in Kerala
}

\author{
Aswathy, $\mathrm{N}^{*}$. and Imelda Joseph \\ Central Marine Fisheries Research Institute, Kochi, Kerala, India \\ *Corresponding author: aswathy.icar@gmail.com
}

\begin{abstract}
Fish farming in open water cages is a recently introduced technology in India. The successful cage farming demonstrations in the open sea led to its popularisation in the coastal waters in the country. The economic viability of cage fish farming was analysed based on primary data collected from 60 farm units in Kerala state in the South west coast of India. Asian seabass, pearlspot, tilpaia, redsnappers and caranx were the major species cultured in the study area. The average size of a farm unit was $115 \mathrm{~m}^{3}$ with a stocking density of 32 fishes per $\mathrm{m}^{3}$. The gross revenue and average cost were ₹ 8584 and $₹ 4331$ respectively per $\mathrm{m}^{3}$ of farm area. The Benefit-cost ratio and operating ratios were 2.02 and 0.42 respectively indicating cage farming as an economically viable farming technology. Resource use efficiency analysis indicated that stocking density and quantity of feed used had positive and significant influence on fish production and economic efficiency could be improved by increasing the use of these inputs.
\end{abstract}

Keywords: Cage farming, cobb-douglas function, economic viability, resource use efficiency

Aquaculture is one of the fastest growing food producing sectors in the world and global aquaculture production reached 106 million $t$ in 2015, with an estimated value of US\$163 billion (FAO, 2017). In India fresh water aquaculture contributes $95 \%$ of the total aquaculture production followed by brackish water shrimp culture (ICAR, 2013). Sea cage farming is of recent origin in India and was popularised by several institutional agencies in the country through front line demonstrations in different maritime states. Cage farming of high value finfishes gained widespread popularity in the maritime states of the country after the introduction of low cost cages and development of seed production techniques for high value finfishes. Cage culture of fishes allows for intensive exploitation of water bodies with relatively low capital investment. The introduction of cage culture into the aquatic ecosystem maximises the carrying capacity per unit area as the free flow of current brings in fresh supply of water and ensures optimum growth by removing the metabolic wastes, excess feed and faecal matter (Vikas et al. 2010).
The farmers in the coastal areas of Kerala state were the pioneers in adopting cage farming in the brackishwater areas in the country. The state located in the southernmost part of India is endowed with abundant coastal and inland water resources. The state contributed an average marine fish production of 5.4 lakh $t$ in 2016 which was $15 \%$ of the total marine fish production in the country. There is an estimated 1.26 lakh ha area of coastal water resources comprising 0.65 lakh ha of brackish waters, 0.46 lakh ha of backwater canals and 0.13 lakh ha of prawn filtration fields in the state (www. fisheries.kerala.gov.in). Even though extensive areas of backwater available for fish culture in the state, most of the areas are currently left unused (Imelda Joseph and Gopalakrishnan, 2017). Cage farming in the coastal waters is of recent origin in the state. The major species cultured were Asian sea bass (Lates calcarifer), pearlspot (Etroplus suratensis), tilapia (Oreochromis sp.), mullet (Mugil sp.), red snappers and caranx. The study was conducted in Ernakulam district where more than $80 \%$ of the cage farms in the state are located. The economic viability analysis 
occupies a key role in micro level investment decisions as well as for developing polices and promotional activities in any sector. Farmers would try to maximise their returns by allocating resources in an efficient manner. The resource use efficiency is a major indicator on how investment, subsidies and credit are used in an efficient manner in farming activities.

Cage farming is a recently introduced technology in India and very few studies focussed on the economic viability of cage farming. The economic viability of cage farming in open sea and reservoirs were studied by many authors (Conte et al. (2008); Das et al. (2009); Narayanakumar et al. (2009); Phimphakan et al. (2013); Christ Ulrik Pedersen (2016), whereas studies in the coastal areas are limited (Azazy et al. (2012) in Egypt; Aswathy, N \& Imelda Joseph in Kerala (2018))

\section{METHODOLOGY}

Ernakulam district $\left(9.9816^{\circ} \mathrm{N}\right.$ and $\left.76.299^{\circ} \mathrm{E}\right)$ in Kerala state was purposively selected for the study as more than $80 \%$ of the coastal cage farms in the state are located in this region. Data on costs and revenues from selected cage farms in Ernakulum district of Kerala was collected during the year 2017. The sample consisted of 60 farmers covering 320 cage farm units installed in the backwaters of Ernakulam district. The sample farmers were selected randomly and consisted of owners of cage farms. The resource use efficiency was studied based on selected variables. The sample farms varied with number and dimensions of cages, cultured species and stocking density. The economic performance of cage farms were analysed using various indicators like Net profit, Operating ratio, Net BenefitEarnings ratio, Benefit-Cost Ratio (BCR) and Return On Investment. Net profit is calculated by deducting all costs including operational expenses, depreciation and interest on fixed capital from the Gross earnings. Other economic indicators used for economic efficiency were calculated as follows.

Operating ratio $=$ Operating costs $/$ Gross revenue

Net benefit earnings ratio $=$ Net Cash Flow (NCF)/Total Earnings (TE)
The ratio expresses the NCF or net benefit as a percentage of TE. A ratio of more than $10 \%$ can be considered as good (Lery et al. 1999, Tietze et al. 2001).

Return on investment $(\mathrm{ROI})=$ Net profit/capital investment

The ratio shows how much money needs to be invested in an enterprise in order to generate a certain level of net profit (Zugarramurdi et al. 1995; Tietze et al. 2001).

\section{Resource use efficiency analysis}

An efficient farmer allocates his resources in an optimal manner, so as to maximise his income, at least cost, on sustainable basis. Multiple regression model used by Emokaro \& Ekunwe (2009), Williams et al. (2012), and Apu Das (2017) was applied to measure the resource use efficiency in cage farming. The following production function model was employed to analyse the resource use efficiency.

$$
\mathrm{P}=\mathrm{F}(\mathrm{A}, \mathrm{S}, \mathrm{F})
$$

$\mathrm{P}=$ Fish production per farm $(\mathrm{kg})$

$A=$ Area of cage farm unit or cage volume in $\mathrm{m}^{3}$

$S=$ Stocking density in numbers

$\mathrm{F}=$ Quantity of feed in $\mathrm{kg}$

\section{Allocative efficiency}

Allocative efficiency was calculated by equating the marginal value product (MVP) of inputs to their respective marginal factor costs (MFC). In order to determine optimal use of a resource keeping the use of other resources constant, MVP and factor cost of their resource were compared. The MVP of each resource is calculated by using the following formula.

$$
\mathrm{MVP}=\mathrm{MPP}_{\mathrm{xi}}{ }^{*} \mathrm{P}_{\mathrm{y}}
$$

Where $\mathrm{MPP}_{\mathrm{xi}}$ is the marginal physical product of the $\mathrm{i}^{\text {th }}$ input (change in output due to a per unit change in the specified input) and $\mathrm{P}_{\mathrm{y}}$ is the price per unit of fish. $\mathrm{P}_{\mathrm{xi}}$ is the cost per unit of the $\mathrm{i}^{\text {th }}$ input obtained by dividing the total cost of the $i^{\text {th }}$ input by the quantity of input. $\mathrm{MPP}_{\mathrm{xi}}{ }^{*} \mathrm{P}_{\mathrm{y}}$ is the value of marginal product and $\mathrm{P}_{\mathrm{xi}}$ is marginal factor cost. Hence allocative efficiency can also be expressed as, 
Allocative efficiency $=$ Marginal value product

(MVP) / Marginal Factor Cost (MFC)

If MVP/MFC equal unity then resource is optimally used. A value of less than unity implies over-use of the resource, and of greater than unity under-use of the resource.

\section{RESULTS AND DISCUSSION}

Cage fish farming is a recently introduced technology in the coastal waters of Kerala. Several institutional agencies including Central Marine Fisheries Research Institute, Fisheries University, State Department of fisheries, and few NonGovernmental Organisations were involved in popularisation of this technology among the coastal fish farmers.

\section{General particulars of cage farmers}

Data were collected from 60 farm units consisting of 320 cages located in Ernakulum district of Kerala state. The panchayat authorities in Ernakulam district issued licenses for installing cages in the coastal waters at specified rates for each culture season based on the size of farm. The average age of respondent farmers was 42 years. The cage dimensions and stocking density adopted by the farmers varied owing to availability of technical and financial resources. The selected farms had an average farm size of $115 \mathrm{~m}^{3}$ with a stocking density of 32 fishes per $\mathrm{m}^{3}$. The dimensions of cages varied from $2 \times 2 \times 1.5 \mathrm{~m}^{3}, 4 \times 4 \times 2 \mathrm{~m}^{3}, 8 \times 4 \times 2 \mathrm{~m}^{3}, 4 \times 4 \times 4 \mathrm{~m}^{3}$, $8 \times 4 \times 4 \mathrm{~m}^{3}$ and $6 \times 6 \times 4 \mathrm{~m}^{3}$. The average feed conversion ratio in the sampled farms was $4.34(79 \mathrm{~kg}$ feed was used for producing $18 \mathrm{~kg}$ fish per $\mathrm{m}^{3}$ ) (Table 1).

Table 1: General particulars of cage farms

\begin{tabular}{ccc}
\hline \multirow{2}{*}{ Particulars } & \multicolumn{2}{c}{ Farm size } \\
\cline { 2 - 3 } & $\mathbf{1 1 5 \mathbf { m } ^ { \mathbf { 3 } }}$ & $\mathbf{1 ~ \mathbf { ~ m }}^{\mathbf{3}}$ \\
\hline Stocking density (no) & 3745 & 32 \\
Feed (kg) & 9082 & 79 \\
Production (kg) & 2090 & 18 \\
Labour days (no.) & 80 & 0.7 \\
\hline
\end{tabular}

Analysis of ownership pattern of the cage farms showed that $55 \%$ of the cage farms in the study area were under single ownership, $28 \%$ owned by selfhelp groups and $17 \%$ through partnership (Table 2).
Table 2: Ownership status of cage farms

\begin{tabular}{ccc}
\hline Category & No & \% \\
\hline Single & 33 & 55.00 \\
Partnership & 10 & 16.67 \\
SHG & 17 & 28.33 \\
Total & 60 & 100.00 \\
\hline
\end{tabular}

\section{Economic viability of cage farming}

The major species cultured in the selected cage farm units consisted of Seabass, Etroplus, Tilpaia, Pompano, Cobia, Redsnappers and Carangids. The yield and revenue per farm were $2.09 \mathrm{t}$ and ₹ 9,90429 respectively. The net profit was ₹ 4,99,957.2 with net benefit earnings ratio of 0.5 and operating ratio of 0.42 . Among the various cost components $56 \%$ of the operational cost was incurred as feed cost followed by seed cost $(21.9 \%)$. The average cost of fish production and price per $\mathrm{kg}$ of fish was ₹ 235 and ₹ 474 respectively. The benefit- cost ratio was 2.02 with return on investment of $241 \%$ (Table 3 $\& 4)$. The economic analysis of sea cage farming in Vizaghapatnam by Narayanakumar et al. (2009) reported the cost of production per $\mathrm{kg}$ of sea bass to ₹ 94.24 against the unit value of ₹ 189.89 per $\mathrm{kg}$. The benefit-cost ratio was on par with that of fish farming reported in other locations. The economics of fish farming in Saki-East Local Government Area (LGA) of Oyo State, Nigeria by Tunde et al. (2015) showed Benefit-Cost Ratio (BCR) of 1.9, indicating fish farming as a profitable venture.

Table 3: Costs and revenues in cage farming (₹)

\begin{tabular}{ccc}
\hline Particulars & $\mathbf{1 1 5}^{\mathbf{3}}$ & $\mathbf{~ m}^{\mathbf{3}}$ \\
\hline Fixed costs & & \\
\hline Cost of cage structure & 191416.7 & 1659.0 \\
Freezer \& accessories & 16133.3 & 139.8 \\
Depreciation & 49968.7 & 433.1 \\
Interest on Fixed capital & 24906.0 & 215.9 \\
Annual Fixed cost & 74875 & 649 \\
\hline Operational costs & & \\
\hline Seed & 91168.8 & 790.2 \\
Feed & 233978.3 & 2027.9 \\
Labour & 64533.3 & 559.3 \\
Other expenses & 25916.7 & 224.6 \\
Gross Revenue & 990429.0 & 8584.1 \\
Total operational cost & 415597.1 & 3602.0 \\
\hline Total cost & 490471.8 & 4250.9 \\
\hline Net profit & $\mathbf{4 9 9 9 5 7 . 2}$ & $\mathbf{4 3 3 3 . 1}$ \\
\hline
\end{tabular}


The economic analysis of cage culture of reservoirs in India by Das et al. (2009) reported the income per crop cultured over 3 months with a working volume of $320 \mathrm{~m}^{3}$ at $₹$ 61,642 with a cost: benefit ratio of 2:20.

Table 4: Economic indicators per $\mathrm{m}^{3}$ of farm area

\begin{tabular}{cc}
\hline Economic indicators & Per $^{3}$ \\
\hline Operating ratio & 0.42 \\
B-C ratio & 2.02 \\
Net- benefit -Earnings ratio & 0.50 \\
ROI (\%) & 241 \\
Cost $/ \mathrm{kg}$ (Rs.) & 235 \\
Price $/ \mathrm{kg}$ (Rs.) & 474 \\
\hline
\end{tabular}

\section{Resource use efficiency analysis}

Among the different production function models tested, Cobb-Douglas form showed the best fit. The parameters of the model estimated using SPSS software follows;

Table 5: Parameters of the regression model

\begin{tabular}{ccccc}
\hline Variables & B & Std error & $\mathbf{t}$ & Sig \\
\hline Constant & -0.708 & 0.271 & -2.612 & 0.012 \\
Stocking density (no) & $0.369^{* *}$ & 0.046 & 8.012 & 0.000 \\
Feed $(\mathrm{kg})$ & $0.614^{* *}$ & 0.028 & 22.212 & 0.000 \\
Farm size $\left(\mathrm{m}^{3}\right)$ & -0.054 & 0.042 & -1.303 & 0.198 \\
\hline
\end{tabular}

$N=60, R 2=0.953, F=381.4$.

** indicates significance at $1 \%$ level.

The estimated production function indicated that feed, seed and farm size together contributed 95\% of variation in fish production in cage farms. Feed and seed used had positive and significant influence on fish production whereas farm size was nonsignificant. Increasing the stocking density by $1 \%$ will increase fish production by $0.369 \%$ whereas increase in quantity of feed by $1 \%$ will increase production by $0.614 \%$ from mean levels.

Resource-use efficiency was estimated for those variables which had significant effect on fish Production. The ratio of marginal value product to marginal factor cost was more than unity for seed (7.91) and feed (10.54) indicating under utilisation of these inputs in fish production and there is scope to enhance profit by increasing these inputs. Similar results were obtained for resource-use efficiency in exotic carp production in Jammu \& Kashmir
(Nisar et al. 2017 and Singh et al, 2009). Resource use efficiency analysis by Apu Das et al. (2017) indicated that stocking density had significant and positive impact on fish production. Resource use efficiency of freshwater fish production system in West Bengal by Rahman et al. (2015) indicated that variables such as fish seeds (0.39), and human labour (0.49) were positive and significant at one percent level. However the results differed from the resource use efficiency models reported by Kingsly et al. (2014) among small scale fish farmers in Nigeria and Azazy et al. (2012) on commercial cage culture in Manzala Lake, Egypt which showed positive coefficients on farm size or cage volume on the economic performance of fish farming.

\section{Conclusion}

Cage fish farming adopted by the farmers in the coastal waters of Kerala was found to be a profitable venture. The cage dimensions and stocking density adopted by the farmers varied owing to technical and financial constraints. There is scope to increase the resource use efficiency by increasing stocking density and quantity of feed used. Considering the vast area of coastal water resources available for culture and profitability of the culture, cage farming may be promoted in the coastal districts of Kerala to enhance the income and livelihood security of fish farmers. However location specific standardisation on number and dimensions of cages to be installed, stocking density and feeding rates suiting the technical and financial constraints of the farmers are essential to harness optimal economic returns and ensure sustainable production system. The successful coastal cage farming in Ernakulum district can be suggested as a model for promoting cage farming in the coastal villages of the country for augmenting fish production and ensuring livelihood security of fisherfolk.

\section{REFERENCES}

Apu Das, Nalini Ranjan Kumar, Rama Sharma and Pradyut Biswas. 2017. Return to Scale and Resource Use Efficiency in Fish Production in Tripura. Fishery Technology, 53: 339 - 343.

Aswathy, N. \& Imelda Joseph, 2018. Economic viability of cage farming of Asian seabass in the coastal waters of Kerala, International Journal of Fisheries and Aquatic Studies., 6(5): 368-371. 
Azazy, A., Hussien A. Hebicha \& Ahmed M. Nasr Allah, 2012. Estimated costs and returns for commercial cage production of fingerlings and table-size mullet (Mugil cephalus) in Dakhlia Governorate, Egypt. Egyptian Journal of Aquaculture.

Christ Ulrik Pedersen, 2016. The economic potential for closed cage fish farming and the total economic value of the wild salmon stock: A literature review, (Unpublished master's thesis). The Arctic university of Norway.

Conte, L., D.Y. Sonoda, R. Shirota \& J.E.P. Cyrino, 2008. Productivity and economics of Nile tilapia Oreochromis niloticus cage culture in South-east Brazil. Journal of Applied Aquaculture, 20(1): 18-37.

Das, A.K., Vass, K.K., Shrivastava, N.P. \& Katiha, P.K. 2009. Cage culture in reservoirs in India (A Handbook). World Fish Center Technical Manual No. 1948. The World Fish Center, Penang, Malaysia.

Emokaro, C.O. and Ekunwe, P.A. 2009. Efficiency of resource use and elasticity of production among catfish farmers in Kaduna, Nigeria. Afr. J. Biotechnol., 8(25): 7249-7252.

FAO, 2017. World aquaculture 2015: A brief overview by Rohana Subasinghe. FAO Fisheries and Aquaculture Circular No. 1140. Rome.

Haque, T. 2006. Resource Use Efficiency in Indian Agriculture, Indian Journal of Agricultural Economics, 61(1): 65-76.

http://www.fisheries.kerala.gov.in.

ICAR, 2013. Handbook of Fisheries and Aquaculture, Indian Council of Agriculture Research publication (ICAR), India.

Imelda Joseph \& Gopalakrishnan, A. 2017. Cage farming headed for equal opportunity in aquaculture development in Kerala, India. Extended abstract. Gender in aquaculture and fisheries: engendering security in fisheries and aquaculture, Asian Fisheries Science Special Issue 30S, 387391, ISSN 0116-6514.

Kingsly Okoi Itam, Ekanan Obasiekong Etuk \& Inibehe George, Ukpong, 2014. Analysis of resource use efficiency among small scale fish farmers in cross s river state, Nigeria. International Journal of Fisheries and Aquaculture, 6(7): 80-86.

Kumar, N.R. 2000. Economics of seed potato production in western Uttar Pradesh. J. Indian Potato Assoc., 27(3-4): 133-139.

Lery, J.M., Pardao, L.J.M and Tietze, U. 1999. Economic viability of marine capture fisheries, Findings of a global study and an interregional workshop, FAO Fisheries Technical Paper No. 377, FAO, Rome, pp. 130.
Narayanakumar, R. 2009. Economic analysis of cage culture of sea bass. In: Course manual: National training on cage culture of seabass. CMFRI \& NFDB, Kochi.

Nisara, U., Kumara, N.R., Yadava, V.K., Sivaramane, N. Prakasha, S. \& Qureshia, N.W. 2017. Economics and Resource-use efficiency in exotic carp production in Jammu \& Kashmir Agricultural Economics Research Review, 30(2): 305-311.

Vikas, P.A., Ratheesh, T.B., Sunny George, Sanil, N.K \& Vijayan, K.K. 2010. Innovative" microsate" cage culture systems for livelihood and nutritional security: a participatory approach. Emilie coudel, Hubert devautour, Christophe-toussaint Soulard, Bernard Hubert. Isda 2010, Jun 2010, Montpellier, France.

Peter Woods \& Michael P. Masser, Cage culture: harvesting and economics. SRAC Publication No. 166.

Phimphakan Lebel, Niwooti Whangchai, Chanagun Chitmanat, Jongkon Promya, Prachaub Chaibu, Patcharawalai Sriyasak, Louis Lebel, 2013. River-Based Cage Aquaculture of Tilapia in Northern Thailand: Sustainability of Rearing and Business Practices. Natural Resources, 4: 410-421.

Rahaman, Sk. M., Ghosh, A., Pal, S. \& Nandi, S. 2015. A comparison of resource use efficiency and constraints of wastewater and freshwater fish production system in West Bengal, Economic Affairs, 60(2): 249-255.

Singh, K., Dey, M.M., Rabbani, A.G., Sudhakaran, P.O. \& Thapa, G. 2009. Technical Efficiency of freshwater aquaculture and its determinants in Tripura, India. Agricultural Economics Research Review, 22(2): 185-195.

Tietze, U., Prado, J., Le Ry, J.M. and Lasch, R. 2001. Technoeconomic performance of marine capture fisheries. FAO Fisheries Technical Paper, 421, FAO, Rome, pp. 79.

Tunde, A.B., Kuton, M.P., Oladipo, A.A. \& Olasunkanmi, L.H. 2015. Economic analysis of costs and return of fish farming in Saki-East local Government area of Oyo State, Nigeria. Journal of Aquaculture Research and Development, 6: 306.

Williams, S.B., Kareem, R.O., Adiegu, C.P. and Dipeolu, A.O. 2012. Resource use efficiency among selected fish farms in Lagos state, Nigeria. J. Agric. Sci., 3(2): 85-94.

Zugarramurdi, A., Parin, M.A. \& Lupin, H.M. 1995. Economic engineering applied to the fishery industry, FAO Fisheries Technical Paper: 351, FAO, Rome. 
